\title{
Covid-19 in Italy : Impact of Lockdown in Italy on Socio-Economic Situation
}

\author{
Yogie Nugraha
}

Universitas Indonesia, Indonesia.

Email: yogie_bricorp@yahoo.com

\begin{tabular}{|c|c|}
\hline ARTICLE INFO & ABSTRACT \\
\hline $\begin{array}{l}\text { Date received : } 09 \text { December } 2020 \\
\text { Revision date : } 10 \text { January } 2021 \\
\text { Date received : } 19 \text { February } 2021\end{array}$ & $\begin{array}{l}\text { The COVID-19 outbreak in Italy ranks third most in the world with } \\
\text { very continued growth over time. The purpose of this article is to } \\
\text { discuss the case of COVID- } 19 \text { in Italy and its impact on socioeconomic }\end{array}$ \\
\hline $\begin{array}{l}\text { Keywords: } \\
\text { Covid-19 } \\
\text { Italy } \\
\text { Impact }\end{array}$ & $\begin{array}{l}\text { life as well as international relations between Italy and other } \\
\text { countries. This article uses library reviews to perform analysis related } \\
\text { to the topic of this article using sources such as academic journals, } \\
\text { research reports, news articles and so on }\end{array}$ \\
\hline
\end{tabular}

Lockdown

Coresponden Author:

Email: yogie_bricorp@yahoo.com

Article with open access under license

\section{INTRODUCTION}

The new Corona virus or Severe Acute Respiratory Syndrome Coronavirus 2 (SARS-CoV-2) that causes COVID-19 (Coronavirus Disease 2019) was first identified in Wuhan, China, in December 2019. The virus then spread to several countries, such as Thailand, Japan, South Korea and the United States. (Song et al., 2020). A number of new cases continue to grow over time and become a significant threat to international health. Until March 11, 2020 the World Health Organization (WHO) designated the COVID-19 outbreak as a pandemic. (WHO, 2020).

Italy - since the beginning of March 2020 - is one of the countries that reported the most positive cases of CoVID-19 in Europe, with approximately $10 \%$ of cases requiring intensive care and more than 35000 cases of death. As a consequence, on March 9, the Italian government imposed a strict lockdown status. This status was initially put into effect in the northern region of Itaia until 10 March 2020 expanding throughout the country and lasting until May 4, 2020. (Paolini et al., 2020). restricting the movement of the population except for reasons of fulfillment of established needs such as employment or health, this is done to avoid the uncontrolled spread of infection throughout Italy. (Silverio et al., 2020).

Analysis of data obtained from civil protection shows that the majority of positive cases and deaths due to COVID 19 are in northern Italy - especially Lombardy, Emilia Romagna, Veneto, and Piedmontwith a declining number of cases heading towards central and southern Italy, as well as some cases in Basilicata. (Li et al., 2020). According Di Lorenzo \& Di Trolio (2020) the most severely affected areas are areas with adequate health services, for example Lombardy and Veneto hospitals are Italy's flagship health centers with adequate protocol and management standards in dealing with many diseases. In addition, there is a passive migration of hospital patients from the south to the north.

A case of COVID-19 in Italy was found on February 21, 2020 in a 38-year-old man being treated at Codogno Hospital in Lodi, Northern Italy. On the same day a similar case was also found in Vo Euaneuo (Padua). Meanwhile, in the Veneto region the first deaths due to COVID-19 were reported from a 78-year-old man at a hospital in padua area. It was the first case to start a series of deaths thereafter. Deaths in the Lambordi region reached a total of 10,022 deaths, higher than the 
death toll in China with 3342 total deaths. (Sartor et al., 2020).

The case of COVID-19 in Italy was the most horrendous event in Italy after World War II, where the death rate was higher than that of China, the country from which the virus originated. italy was the first European country with confirmed positive cases and spread rapidly.

Many Italians are not prepared for the virus as a result of inadequate health protection equipment such as masks for the public, especially for health workers, inadequate ventilators and a high number of infected elderly people are also the cause of the increasing death rate in Italy. (Indolfi \& Spaccarotella, 2020).

\section{METHOD}

The design of this research is Literature Review which is to collect data or sources related to a particular topic obtained from various sources such as books, journals, encyclopedias, newspapers, magazines and other libraries. Literature review is or critically review the knowledge, ideas or findings in a library and formulates theoretical and methodological contributions to a particular topic. The nature of this research is descriptive analysis that is the regular decomposition of data that has been obtained and then given understanding and explanation in order to be well understood by the reader.

\section{RESULTS AND DISCUSSION}

\section{Why Are Deaths in Italy So High?}

According (Di Lorenzo \& Di Trolio, 2020), the percentage of deaths is determined by dividing the number of deaths due to COVID-19 by the total number of confirmed positive cases of COVID-19 cases. In Italy, the mortality rate is $9 \%$ in Lombardy $(>10 \%)$, while the kematain rate in Wuhan is $5.8 \%$ and the remaining $<1 \%$ in China. The high mortality rate in Italy is likely due to the average age of infected Italians higher than in other countries, for example with China and Korea, where the number of confirmed CASES of COVID-19 is young women with a percentage of $62 \%$ and $30 \%$ of positive cases are in the age of $20-30$ years. Meanwhile, in Italy the average age of cases of death due to COVID-19 is 79 tahum, and more than $70 \%$ are male. In addition, the high mortality rate is likely due to the presence of other congenital diseases suffered by COVID-19 patients and are in their twilight years. Who reports that COVID-19 patients without congenital diseases have a $1.4 \%$ mortality rate while COVD-19 patients with dangerous congenital diseases have a higher mortality rate of $13 \%, 9 \%$ and $7.6 \%$ for patients with congenital diseases such as cardiovascular, diabetes, and cancer. Quoted from TIME magazine, the spread of the virus went undetected, long before the first case was confirmed, the virus had long spread in Italy.

In addition to the aforementioned causes, Italian cultural culture is also one of the causes of this virus by spreading rapidly. One of italian culture is the habit of making physical contact with others, such as hugging each other and kissing the cheeks of family or close friends and the lack of distance between each other while talking. Large social gatherings, especially in publlik areas are part of their daily lives. In addition, two-thirds of Italians live in urban areas with high levels of population density (Belligoni, 2020). This of course further accelerates the spread of the COVID-19 outbreak and extends the list of positive cases.

\section{Lockdown Italy Policy}

The Italian government imposed a total lockdown status across the country on March 10, 2020, three years after the first case was confirmed. However, McCann et al. (2020) that the instruction is late in effect. This suggests that Italy initially underestimated the COVID-19 outbreak. Although in the northern regions of Italy has been put in lockdown, but some cafes and bars are still open until $6 \mathrm{pm}$. The cathedral in Milan is also still open to accepting tourists while new cases continue to emerge. Lockdown information in italy's northern regions was also leaked before the ban was put in place so that people had already left the area. This adds to the long list of new cases that are constantly popping up. The peak of the first wave of pandemics is in early March to April 2020, where the number of deaths reaches almost 1000 deaths per day. (Ortenzi et al., 2020). Scientists argue that Italian authorities did not act decisively to stop the virus at the start of the outbreak, the government tends to underestimate the dangers of vurs and miscalculate the rate of spread of the virus.

Even so, the lockdown policy had a fairly positive impact to prevent the spread of the outbreak. This is evident from the significant decrease in the number of new cases after the lockdown policy was put in place in the Lodi and Padua areas. The number of COVID-19 cases decreased in the summer. Unfortunately, European 
countries including Italy are again facing a second wave of COVID-19 outbreaks (Bontempi, 2021). In September 2020, the government re-opened schools, although it continued to implement health protocols but new cases of the COVID-19 outbreak began to increase significantly in major Italian cities such as Milan, Naples and Rome. This is according to (Chirico et al., 2021) probably caused by two things. (1) the public transport system opened to support the reopening of schools and businesses, local and local governments will not reorganize the transportation system to minimize the risk of COVID-19 transmission so that public transportation becomes congested; and (2) the opening of the company's kemballi and re-activity as usual.therefore, since the beginning of October 2020 all epidemological indicators such as new cases are confirmed, the number of serious or critical cases and the number of new deaths increases rapidly. As of December 2, 2020, the total number of COVID-19 cases registered in Italy was $1,601,554$ cases, 407,791 of which were registered in Lombardy (Varrella, 2020). The second wave of the outbreak shook the region as badly as the first wave.

\section{Socio-Economic Impact of Italy's Lockdown Policy}

Italy was the first European country to initiate national mitigation measures (social distancing, isolation for confirmed positive and suspected cases, and the closure of schools and universities) that led to the suspension of all nonsensical production in the country from early March to early May 2020. Activities deemed uninsportant, including public administration activities, are still permitted to continue operating by imposing remote work.

According Giuffrida (2020), lockdown policies also have an impact on people's mental health. A recent survey showed that eight out of ten Italians admit that they need psychological support to get through a pandemic crisis. This is because they experience anxiety about the virus, the emotional impact of physical distance, and economic pressures during this pandemic. Psychologists argue that increased anxiety and depression are strongly associated with isolation policies. Italy also suffered a financial recession, even making Italian society struggle to cope with this. They began to worry about how to meet basic needs because of job losses. Since the beginning of March many people have difficulty in dealing with this sitauasi. What's more, they have not received the assistance promised by the government. To deal with this impact, the government also provides tollfree numbers so that people get psychological support during this crisis. The Italian Society for Emergency Psychology also helped deal with psychological problems during the pandemic. The agency has helped 750 residents struggling in anxiety, loneliness, fear and panic attacks. Many psychologists also volunteer to provide free consultations. (Perrone, 2020).

Public finances also declined due to the COVID-19 crisis. GDP is projected to shrink by $8 \%$ (compared to the predicted increase before COVID of $0.6 \%$ ), the public deficit increases from $2.2 \%$ to $10.4 \%$, public debt to GDP increases to $155.7 \%$ (from before COVID forecast of $135.2 \%$ ) and the unemployment rate to $11.6 \%$. Experts estimate that of italy's 10 million people, a fifth of the number of adults, will fall into poverty and unable to meet vital spending on food, medicine and homes. (Bull, 2020). The government is facing this by providing 3.3 billion euros from the central government to local governments to be distributed to people who do not receive benefits and to cover $80 \%$ of salaries during the lockdown. In addition, the government also allocates 30 billion euros to affected companies for freelancers and guarantees short-term funding (credit and loans) of up to six years. (Mascio et al., 2020). On March 29, the National Civil Protection also sent 400 million euros to all municipalities for their residents to purchase food vouchers and basic necessities based on population and income criteria. (Sanfelici, 2020).

\section{Crisis in Italy During Covid-19 Pandemic: Request for Help Does Not Get Positive Response}

On 26 February 2020 new confirmed cases tripled every 48 hours, Italian Prime Minister Giuseppe Conte appealed for help to fellow EU member states. Hospitals in Italy are overwhelmed, doctors and nurses are running out of the maxer, gloves and aprons needed to keep themselves safe. Medics were forced to put the lives of critically ill people to God because of a lack of ventilators. Quoted by The Guardian, the Italian government sent an emergency message from Rome to the Berlaymont European Commission headquarters in Brussels. Specifications of Italian needs are uploaded to the EU's Common Emergency Communication and Information System (CECIS). However, the request did not receive a positive response. Janez Lenarčič, the European Commissioner in charge of crisis management, said that the lack of a positive response to Italy's request was not due to a lack of solidarity, but because 
other countries were just as unprepared as Italy. (Boffey et al., 2020).

Moreover, there has been a refusal by northern European countries to support mutual ties in a "recovery bond" on behalf of all EU zone countries to help fund the rebuilding of a national economy that is expected to sink deep into recession. However, conservative leaders in rich countries such as Germany, the Netherlands, and Austra disagreed with the idea, especially with heavily indebted countries such as Italy. On the other hand, Comission President Urusula von der Leyen apologized to Italy for the lack of solidarity of European countries in dealing with the COVID-19 crisis and offered assistance in dealing with the economic impact. He said the E.U. would allocate more than 100 billion euros ( $\$ 109.62$ billion) to the most affected countries, starting with Italy to help cover lost wages and to maintain jobs. (Lenoir, 2020).

\section{Impact of Italy's Covid Outbreak on International Relations}

Amid a lack of response from both European and U.S. countries, China is the country that provides assistance to Italy. In early March, medics and tons of medical equipment were brought by China to Italy. The Chinese Embassy conducted a successful campaign through social media to emphasize acts of solidarity, and the italian government publicly praised the initiative. however, many people who judge the acts of solidarity campaigned by China have another goal, namely to raise softpower and change the narrative about the outbreak of pandemics. In response, the United States also took action. In late March 2020, Trump announced sending $\$ 100$ million in medical support to Italy and signing a Memorandum of Assistance for COVID-19 to the Republic of Italy. China's initiatives are proving more effective according to public acceptance. As SWG srvei points out in EInternatioal Relation, the percentage of Italians who consider China to be a friendly country has jumped from $10 \%$ in January to more than $50 \%$ in March. In addition, an average of $36 \%$ of the Italian public view China as the best international ally, while the percentage of public assessment of Italians is about $30 \%$. During the COVID-19 crisis, timing was critical and China responded quickly and precisely, while America (and Europe) were judged to be slow and less spectacular even though qualitatively and quantitatively superior (Catapano, 2020).

Some of the main issues can be identified from COVID-19 cases occurring in Italy. The increase in positive cases in Italy is largely due to bias and policy changes in patient testing. People with severe symptoms are more likely to be tested than people who do not have symptoms, Common tests used for the diagnosis of COVID1-19 may be inaccurate and their validity is poor where standard procedures for covid-19 tests are not enforced in all regions. Italy's population is relatively old ( average age $=47.3$ years) where the case fatality rate (CFR) of Covid-19 is higher for the elderly. Moreover, Italy's culture away from the habit of 'social distancing" is exacerbating the positive case in Italy. On the other hand 'social distansing' creates serious consequences in various aspects of life, ranging from social interaction (especially in the proes empathy), economic level, employment and infrastructure gaps.

Regarding the psychological impact on society, it is worth remembering that Italy was the first country in Europe to be affected by the COVID19 pandemic, the first country in Europe to implement a lockdown, and also the country with the highest positive case in Europe at the time. This most likely made Italians feel more unlucky compared to other countries in Europe which then adversely affected their emotional and psychic condition at the time. But on the other hand it also evokes their solidarity -- among italians - even the world community in the face of the covid-19 pandemic, this can be seen on various social media at that time where almost all the world community support each other.

The solidarity of the world's countries in the face of COVID - aid to Italy - is enough to help Italy, China For example. Although the EU was initially considered to lack solidarity in the face of the pandemic, especially when the EU's lack of rapid response to Italian aid requests, in the end the EU provided substantial assistance. Despite the CoVID19 pandemic, Italy-Europe relations have indeed deteriorated before. This tension is triggered by various events that are mostly triggered by political and economic problems.

\section{CONCLUSION}

Italy is the first country to be infected with COVID-19 and is the third country with the most cases of infection in the world. The Italian government is considered unprepared and late in the face of the COVID-19 outbreak resulting in confirmed positive cases and massive kematain numbers. The government is trying to suppress the increase in new cases by implementing a gradual lockdown policy until the total lockdown. This policy finally succeeded in lowering the curve of COVID-19 
sufferers. In addition, the government has also managed to overcome the impact of COVID on picological and economic social problems through cooperation with various parties including, masayrakat Italia itself.

\section{REFERENCES}

Belligoni, S. (2020). 5 reasons the coronavirus hit Italy so hard. The Conversation.

Boffey, D., Schoen, C., Stockton, B., \& Margottini, L. (2020). Revealed: Italy's call for urgent help was ignored as coronavirus swept through Europe. This Is Europe.

Bontempi, E. (2021). The europe second wave of COVID-19 infection and the Italy "strange" situation. Environmental Research, 193(November 2020), 110476. https://doi.org/10.1016/j.envres.2020.110476

Bull, M. J. (2020). Coronavirus: lessons from Italy on the difficulties of exiting lockdown. The Conversation.

Catapano, C. (2020). COVID-19's Reshaping of International Alignments: Insights from Italy. E-International Relation.

Chirico, F., Sacco, A., Magnavita, N., \& Nucera, G. (2021). Coronavirus disease 2019: the second wave in Italy. Journal of Health Research, ahead-of-print(ahead-of-print). https://doi.org/10.1108/jhr-10-2020-0514

Di Lorenzo, G., \& Di Trolio, R. (2020). Coronavirus Disease (COVID-19) in Italy: Analysis of Risk Factors and Proposed Remedial Measures. Frontiers in Medicine, 7 April), 23-26. https://doi.org/10.3389/fmed.2020.00140

Giuffrida, A. (2020). Italy's lockdown has taken heavy toll on mental health, say psychologists. The Guardian.

Indolfi, C., \& Spaccarotella, C. (2020). The Outbreak of COVID-19 in Italy Fighting the Pandemic. JACC: C ASE REPORTS, 2(9), 1414-1418. https://doi.org/10.1016/j.jaccas.2020.03.012

Lenoir, F. (2020). European Commission apologises to Italy for lack of help in coronavirus crisis. France 24.

Li, R., Pei, S., Chen, B., Song, Y., Zhang, T., Yang, W., \& Shaman, J. (2020). Substantial undocumented infection facilitates the rapid dissemination of novel coronavirus (SARS-CoV2). Science, 368(6490), 489-493. https://doi.org/10.1126/science.abb3221
Mascio, F. Di, Natalini, A., \& Cacciatore, F. (2020). Public Administration and Creeping Crises: Insights From COVID-19 Pandemic in Italy. American Review of Public Administration, 50(6-7), 621-627. https://doi.org/10.1177/0275074020941735

McCann, A., Popovich, N., \& Wu, J. (2020). Italy's Virus Shutdown Came Too Late. What Happens Now? The New York Times.

Ortenzi, F., Albanese, E., \& Fadda, M. (2020). A transdisciplinary analysis of covid-19 in italy: The most affected country in europe. International Journal of Environmental Research and Public Health, 17(24), 1-12. https://doi.org/10.3390/ijerph17249488

Paolini, D., Maricchiolo, F., Pacilli, M. G., \& Pagliaro, S. (2020). COVID-19 lockdown in Italy: the role of social identification and social and political trust on well-being and distress. Current Psychology. https://doi.org/10.1007/s12144-020-01141-0

Perrone, A. (2020, April). "The Strength of Ordinary People." The Creative Ways Italians Are Supporting Each Other During Their Coronavirus Lockdown. Time.

Sanfelici, M. (2020). The Italian Response to the COVID-19 Crisis: Lessons Learned and Future Direction in Social Development. The International Journal of Community and Social Development, 2(2), 191-210. https://doi.org/10.1177/2516602620936037

Sartor, G., Del Riccio, M., Dal Poz, I., Bonanni, P., \& Bonaccorsi, G. (2020). COVID-19 in Italy: Considerations on official data. International Journal of Infectious Diseases, 98, 188-190. https://doi.org/10.1016/j.ijid.2020.06.060

Silverio, A., Di Maio, M., Ciccarelli, M., Carrizzo, A., Vecchione, C., \& Galasso, G. (2020). Timing of national lockdown and mortality in COVID-19: The Italian experience. International Journal of Infectious Diseases, 100, 193-195. https://doi.org/10.1016/j.ijid.2020.09.006

Song, F., Shi, N., Shan, F., Zhang, Z., Shen, J., Lu, H., Ling, Y., Jiang, Y., \& Shi, Y. (2020). Emerging 2019 novel coronavirus (2019-NCoV) pneumonia. Radiology, 295(1), 210-217. https://doi.org/10.1148/radiol.2020200274

Varrella, S. (2020). Statista Research Department: Coronavirus (COVID-19) in Italy - Statistics \& Fact. Statistia. 